\title{
ELEMENTARY STEPS IN HETEROGENEOUS CATALYSIS: THE BASIS FOR ENVIRONMENTAL CHEMISTRY
}

\author{
PODSTAWOWE KROKI W KATALIZIE HETEROGENNEJ: \\ PODSTAWY DLA CHEMII ŚRODOWISKA
}

\begin{abstract}
Catalysis is an alternative way for reaching an immediate formation of a product, because of a lower energy barrier (between the molecules and the catalysts). Heterogeneous catalysis comprises the acceleration of a chemical reaction through interaction of the molecules involved with the surface of a solid. It is a discipline, which involves all the different aspects of chemistry: inorganic and analytical chemistry in order to characterize the catalysts and the forms of these catalysts. The industrial chemistry puts all these things together to understand the solid chemical handling, chemical reaction and energy engineering and the heat and mass transfer in these catalytic processes. Very often there are more than one, but several products, then the role of the catalyst is not so much related to activity, but to selectivity. The underlying elementary steps can now be investigated down to the atomic scale as will be illustrated mainly with two examples: the oxidation of carbon monoxide (car exhaust catalyst) and the synthesis of ammonia (the basis for nitrogen fertilizer). There is a huge market for the catalysts themselves despite of their high costs. A large fraction is used for petroleum refineries, automotive and industrial cleaning processes. The catalytic processes is a wide field and there are still many problems concerning energy conservation and energy transformation, so there is much to do in the future.
\end{abstract}

Keywords: heterogeneous catalysis, environmental chemistry, oxidation of carbon monoxide, synthesis of ammonia

\footnotetext{
${ }^{1}$ Fritz-Haber-Institut der Max-Planck-Gesellschaft, Berlin, Germany

${ }^{2}$ Chair of Biotechnology and Molecular Biology, University of Opole, ul. kard. B. Kominka 6, 45-032 Opole, Poland, phone +48 7740160 42, email: maria.waclawek@o2.pl

${ }^{3}$ Paper prepared on the basis of Prof. Gerhard Ertl lecture delivered during the 23th annual Central European Conference ECOpole'14, Jarnoltowek 15.10.2014. Background image of the slides was taken from: https://www.youtube.com/watch?v=BQD0EEdQPQo\&feature=youtu.be

* Corresponding author: mrajfur@o2.pl
} 


\section{Catalysis and environment}

- automotive exhaust catalysis,

- catalysis for clean air, water, and soil,

- catalysis for sustainable energy conversion,

- chemicals for the environment,

- the use of renewables.

\section{Catalytic removal of toxic substances}

\begin{tabular}{c|c|c} 
Toxic substance & Source & Removal \\
\hline hydrocarbons & $\begin{array}{r}\text { chemical/petroleum } \\
\text { industry } \\
\text { solvents } \\
\text { car exhausts }\end{array}$ & oxidation \\
\hline carbon monoxide & car exhausts & oxidation \\
\hline sulfur dioxide & powerplants \\
heating & reduction
\end{tabular}


Catalysis is mainly used in the removal of toxic substances.

These can be hydrocarbons - the source is chemical

or petroleum industry, solvents and car exhausts and its main reaction is oxidation.

Then carbon monoxide - the main reaction is also oxidation and its main source are car exhausts. Sulfur dioxide - in power plants and heating, it is much more complicated to remove. And finally, nitric oxides, that comes from car exhausts and power plants, but the main reaction here is reduction.

So, as you can see, there are different toxic pollutants which can be removed by oxidation or reduction. The best would be to find a way, where both these processes could take place.

\section{Total emissions of pollutants in West Germany 1989}

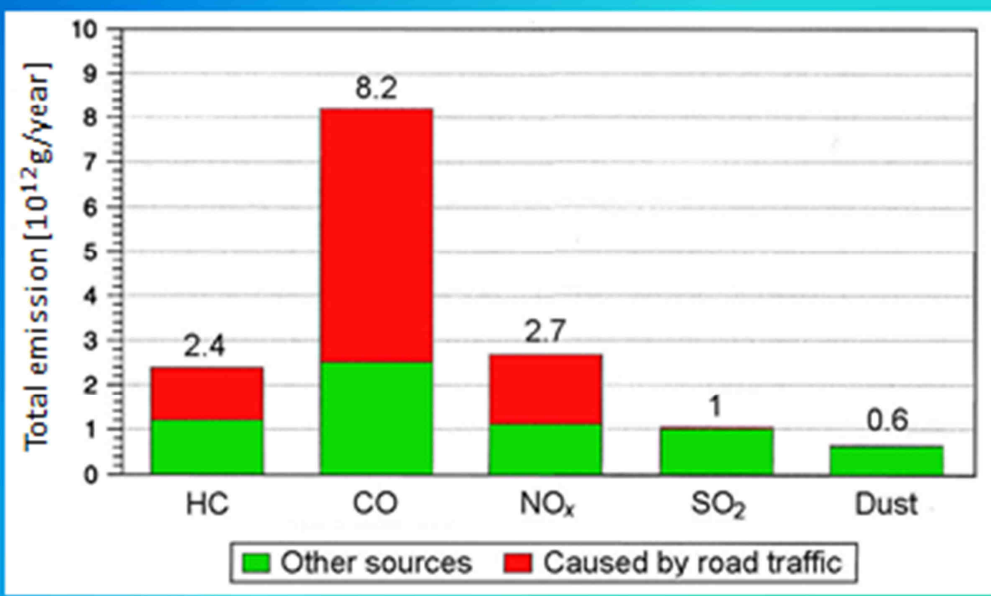

This is the total emission of pollutants in the air in West Germany in 1989. These are (from left to right) hydrocarbons $(\mathrm{HC})$, carbon monoxide $(\mathrm{CO})$, nitric oxides $(\mathrm{NO} x)$, sulfur dioxide and dust. And the red bars represent what is caused mainly by the traffic. We can observe that the main exhaust of carbon monoxide is through cars (as a traffic). 


\section{Progress of a chemical reaction}

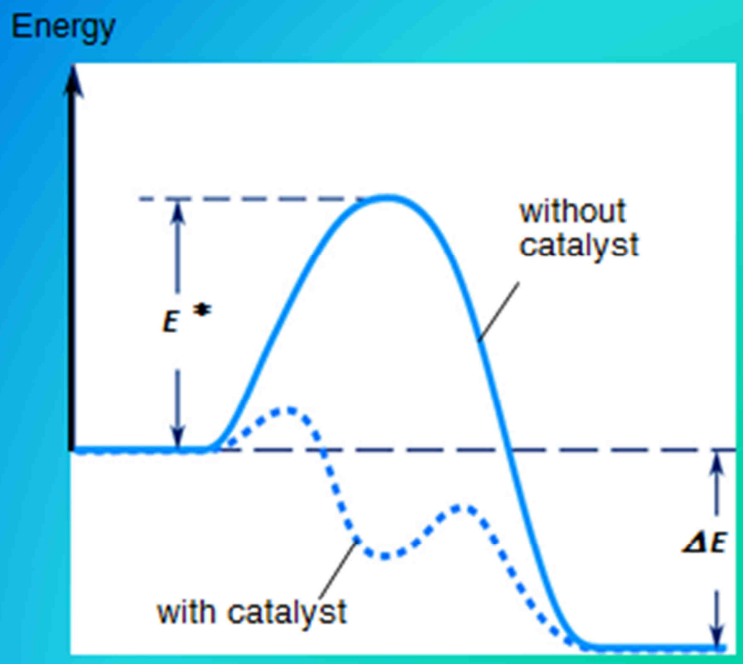

Catalysis is an influenced chemical reaction with the presence of a substance which itself is not a part of reaction product.

If you look at the chemical reactions, it always involves breaking and formation of new bonds. And if you look at a progress of a chemical reaction, in order to go from a reacting molecule to a product, we have to overcome an energy barrier for breaking bonds. And these energy barriers determine its rate.

Catalysis is now an alternative way for reaching as an immediate formation of a product, because of a lower energy barrier (between the molecules and the catalysts). So catalysis research is mainly associated with identifying and characterizing the intermediates between catalysts and reacting molecules. 


\title{
Industrial Catalytic Processes
}

\author{
Importance of Catalysis
}

All Processes

Catalytic Processes
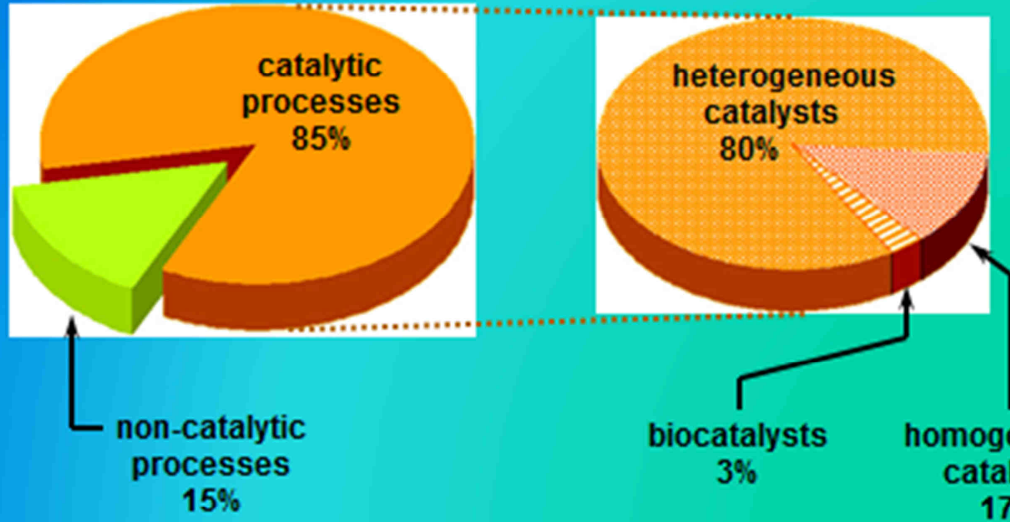

biocatalysts homogeneous

$3 \%$

catalysts

$17 \%$

\section{Development of the catalyst market}

(in millions of dollars)

Total:

United States

Worlowide

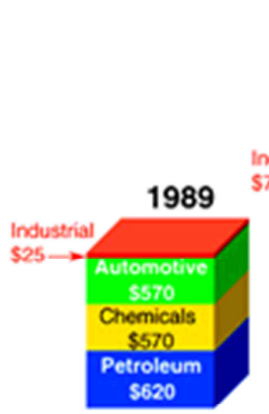

$\$ 1,785$

$\$ 5,100$

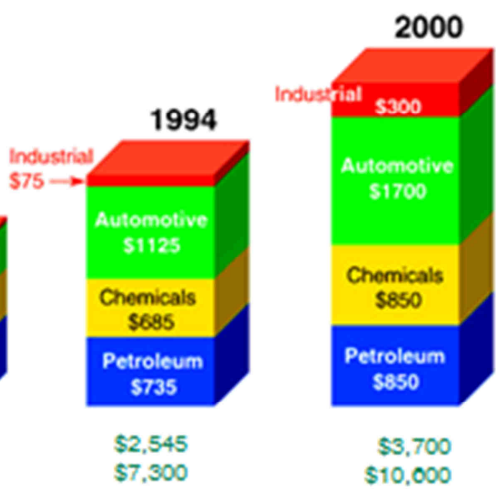

There is a huge market for the catalysts themselves. A large fraction is used for petroleum refineries, automotive, exhaust catalysts and industrial cleaning processes. There is a continuous increase of the market despite of high catalyst costs. These are all billions of dollars. 


\section{Heterogeneous catalysis}

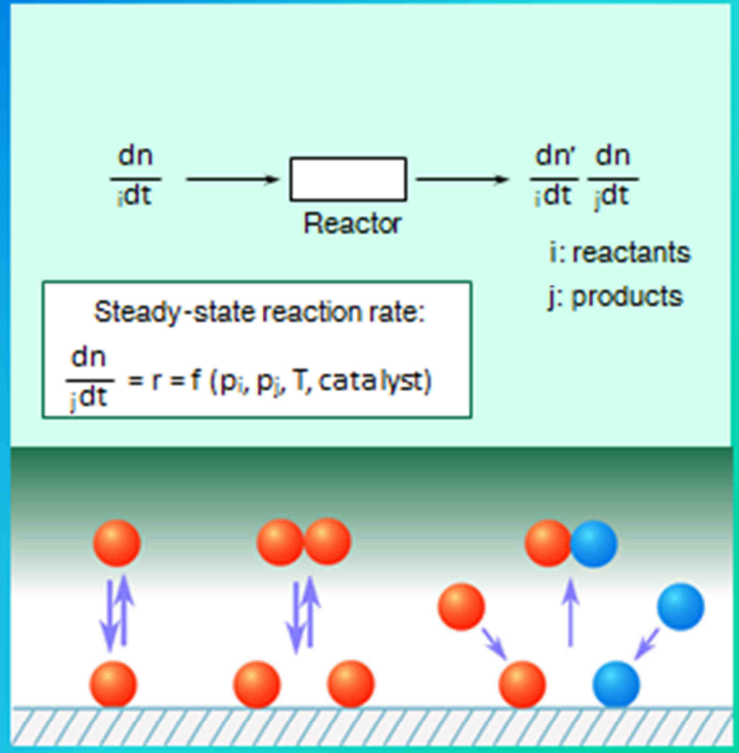

What is the principal of the heterogeneous catalysis?

We have a reactor where the reaction should take place. The reacting molecules flow through the reactor with a certain rate and the product is leaving the reactor as a continuous flow of the reacting molecules. The catalyst itself (in this case it is solid) is exposing its surface to the molecules arriving at the surface in the gas phase. Some atoms at the surface of the solids are missing some of the nearest neighbors. They can form new bonds with the molecules arriving from the gas phase. This new bonds formation may be associated with another bonds breaking through dissociation. The molecules can migrate across the surface, they can find another partner and form a new molecule, which is then released back into the gas phase. The sequence of all the steps determines the overall rate. So the question is: how can we get information about all the individual steps? 


\section{Typical composition of gasoline powered car exhaust gas}

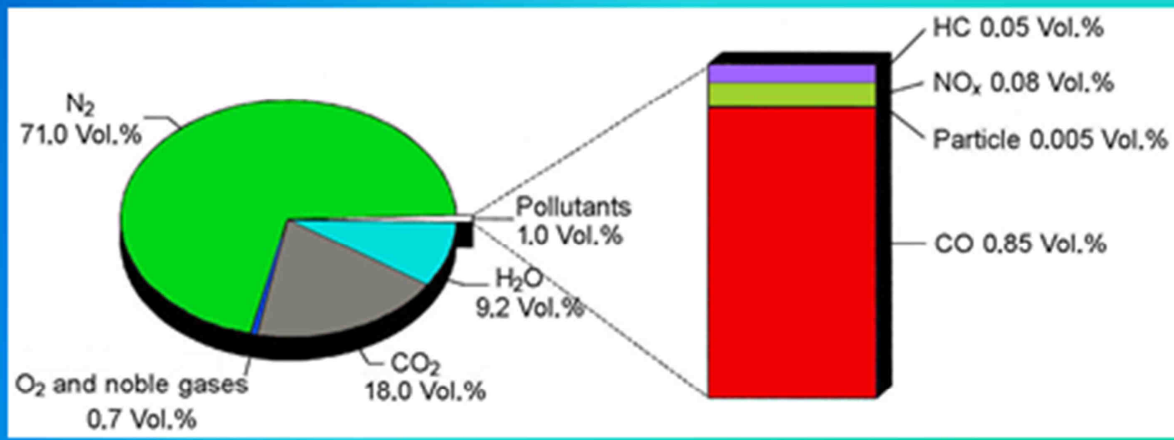

The typical composition of the exhaust from the engine powered by gasoline is, of course, nitrogen from the air, $\mathrm{CO}_{2}$ (which is a problem, of course), water and about $1 \%$ of pollutants. It is a pupose of the car exhaust catalysts - to remove these pollutants, which consist mainly of carbon monoxide, small fraction of nitric oxides and hydrocarbons. Some regulations were introduced to remove these pollutants from the exhaust by proper catalysts.

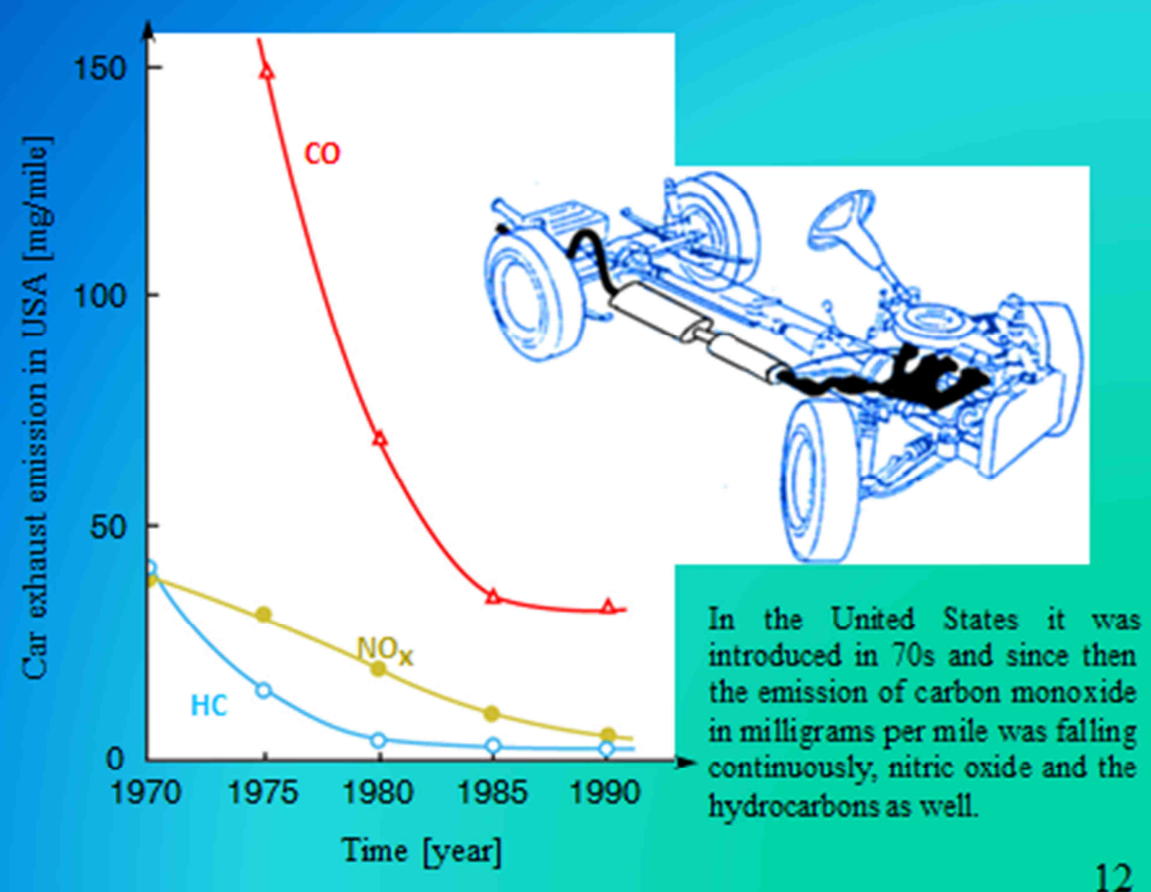




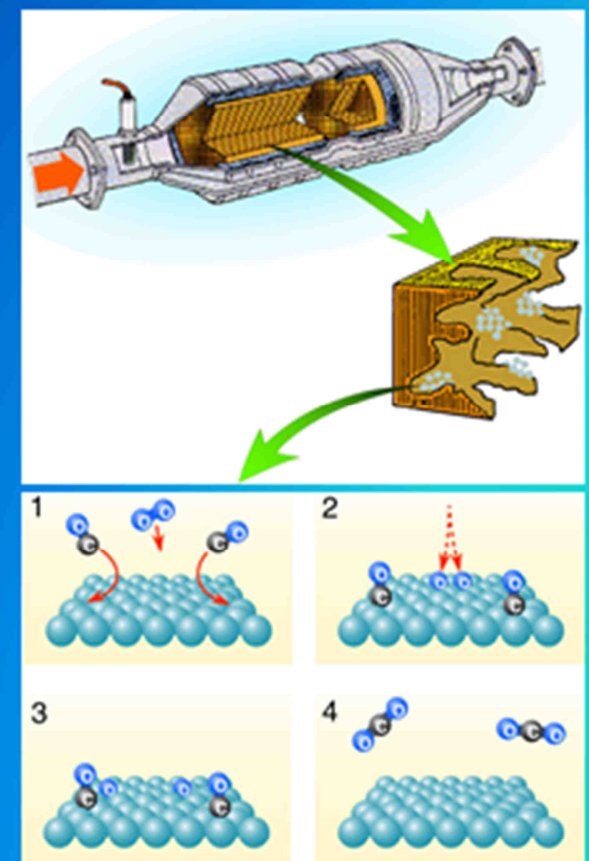

\section{How is this performed?}

In your car there is a device that is a porous support medium of oxide, the so-called 'wash code', under which small particles of preachers materials like platinum, palladium or rhodium are deposited and these surfaces are exposed to the molecules from the gas phase and these molecules are interacting with the surfaces. The carbon monoxide molecules are absorbed through the carbon atom, like in a carbonyl compound, the oxygen molecules may be dissociated, so then we have oxygen atoms chemisorbed. And carbon oxide molecules chemisorbed semi migrate and meet each other, react and form a new substance, which is then released back in the gas phase.

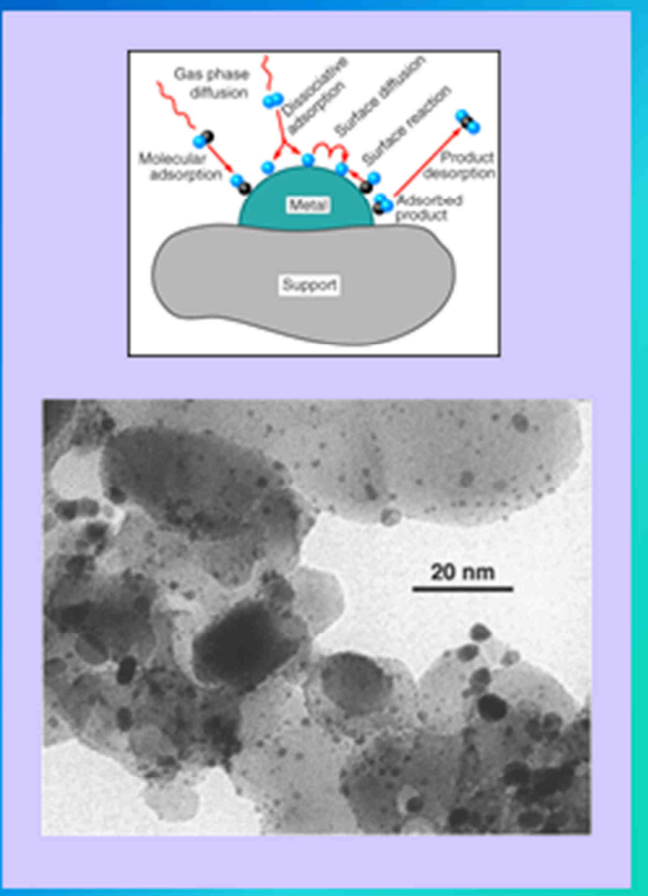

There are typical supported catalyst particles of platinum and oxide support. There are very small particles, in the nanometer range dimension, and that is why catalysis has been a nanoscience, nanotechnology long before the system was invented. The higher distortion, the bigger surface area per gram. And here is such particle on a support and on the surface of this particle such processes take place: the desorption, dissociation, diffusion. Media react and power is lead back to the gas phase. 

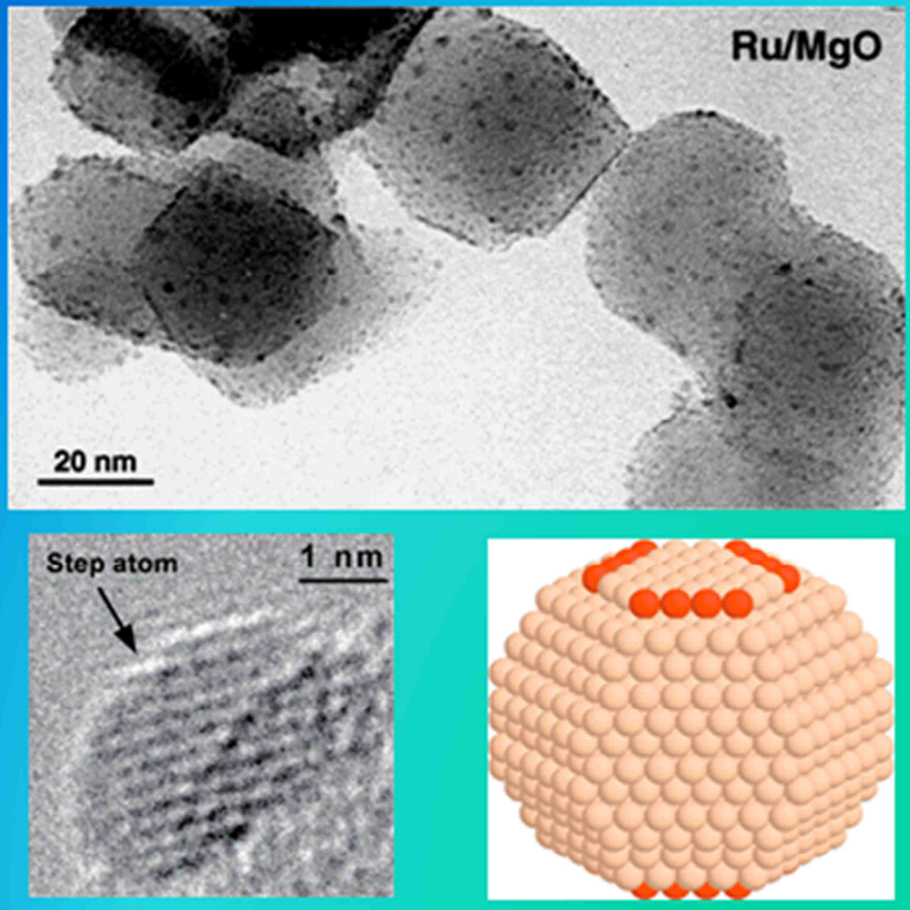

These are supported ruthenium particles on a magnesium oxide support. This is a high resolution electron micrograph of such a catalyst particles with one nanometer. See how the metals are exposing different crystal plains, exposing also crystal defects and we can assume that all these different sites have different reactivity. This makes a heterogeneous catalysis such a complicated process. In order to get information about the elementary processes, we have to look at the properties of these individual crystal plains. That is the so-called 'surface science approach'. This can be done by using single crystals - looking at the single crystal surfaces with atomic resolution. 


\section{$\operatorname{AlAl}(111)(111)$}



$4.6 \mathrm{~nm} \times 7.1 \mathrm{~nm}$

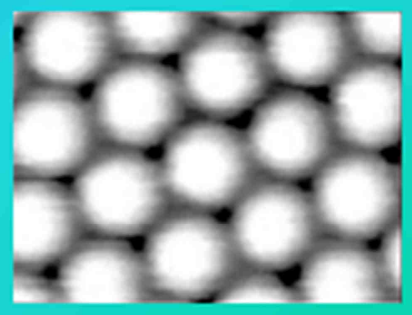

$1.3 \mathrm{~nm} \times 0.9 \mathrm{~nm}$

This can be done, for example, by the scanning tunneling microscope. This picture shows an aluminium-111 with atomic resolution - perfect arrangement of the surface atoms, even in a larger scale. These are our model systems with which we can study these elementary steps. Aluminum itself is not a good catalyst.

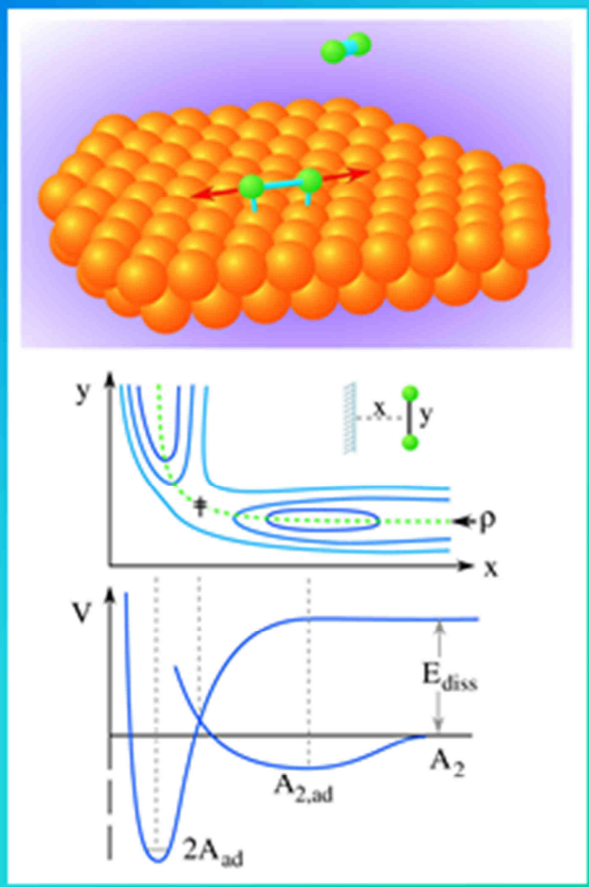


Diatomic molecules approach at the surface and if the molecule approaches the surface, this is a potential set end, there will be a weak attractive interaction between the molecule and the surface. The minimum characterizes the adsorption of the molecule. If instead we dissociate the molecule before and we approach these atoms to the surface, the atoms will make a strong bond. There can be crossing of these two potential surfaces, which marks an activation barrier that has to be overcome for the molecule to dissociate, in order to be absorbed. This is a secret of the catalyst - this barrier should not be too high, because the higher the barrier, the lower her public liability. The bonding of the atoms also should not be too strong, because they have to react first and since only certain metals or catalysts have this optimum condition, the car exhaust catalyst is adjusting to the metals of the platinum core. This is a two dimensional presentation. If you plot the distance of the molecule from the surface $\mathrm{X}$ and the separation between the two atoms Y, we have this kind of counter plots - we see that the molecule which approaches the surface has a shallow minimum, which is a molecular state here. It overcomes the barrier and the atoms separate from each other. This way the energy is gained - the adsorption energy that has to be released in the solid. That is why these two atoms usually will not stay together, they will fly apart from each other. During this time, it is needed to dissipate the energy to the solid.

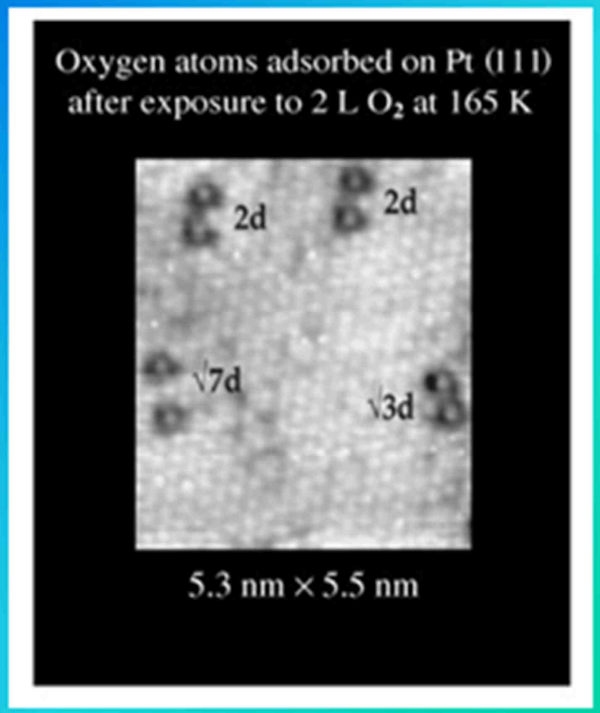

[1] Winterlin J, Schuster R, Ert1 G. Phys Rev Lett. 1996;77:123-129. 
If we look at a surface like platinum after the exposure to oxygen at low temperature, we find pairs of new structures. These are the oxygen atoms and they are separated by $5-8$ angstroms from each other, so they are not in the nearest neighbor sites. Just because of this we need more time - 10-13 seconds that is a typical elementary time for molecule motions on the surface for separation. And then there are atoms, and their low temperature saves the immobilization of them. The bright dots are the positions of the oxygen atoms, they are rounded by dark areas, that is because this technique probes also the electronic properties of the surface. Oxygen is electronegative, it withdraws the electronic chart from the substrate and there is a kind of lowering of electron density around the oxygen atoms. As a consequence, the local electronic properties of a substrate are disturbed and this causes some interactions between the particles. It can be attractive, as well as repulsive.

This is a flat, perfect platinum surface, where we have the dissociation. We have seen before that such a surface has defects, the typical defect is monotonic step. These steps can have very strong influence on the reactivity.
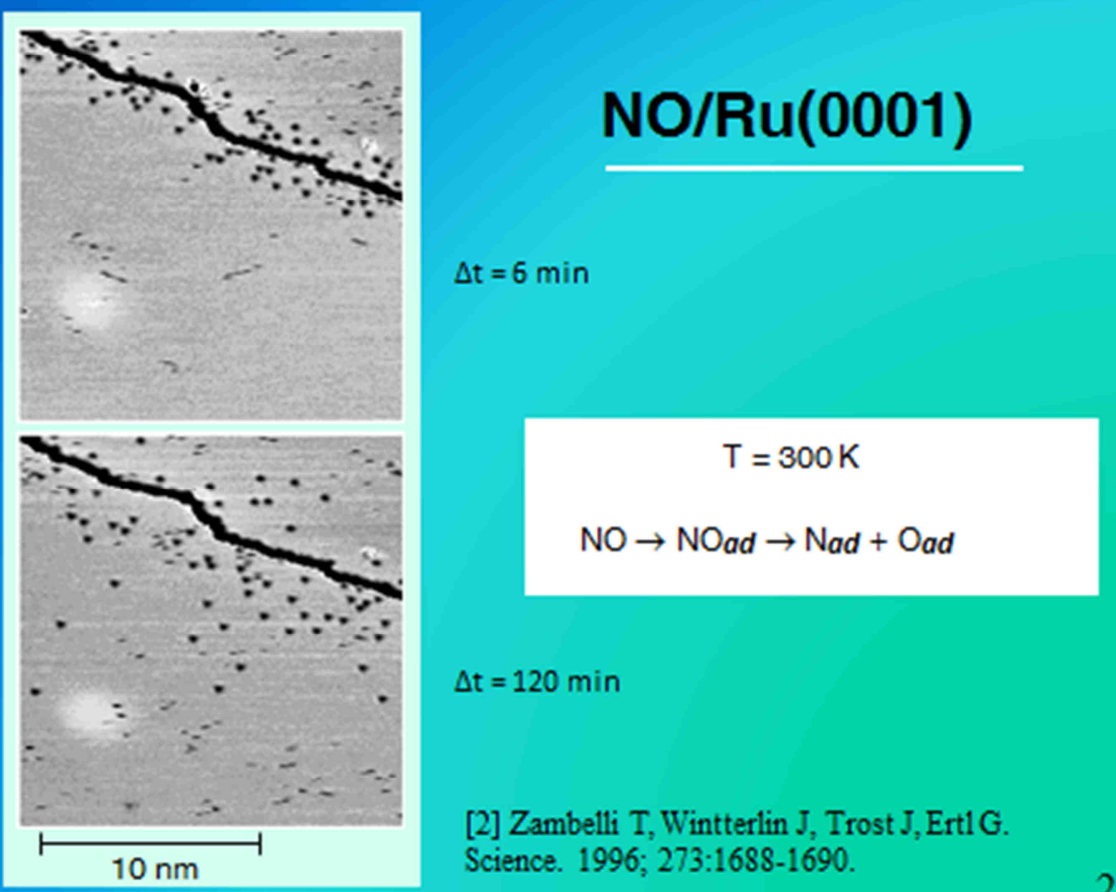
It is shown here - this is NO on a ruthenium surface.

This is a monoatomic step and after six minutes of exposure to a small amount of nitric oxide, we find two new features (dark points on the picture are nitrogen atoms and the strings are oxygen atoms). The oxygen atoms are more mobile and can migrate across the surface, so nitrogen atoms are strongly held and need more time to move away from the steps. The steps act as active sites in this case.

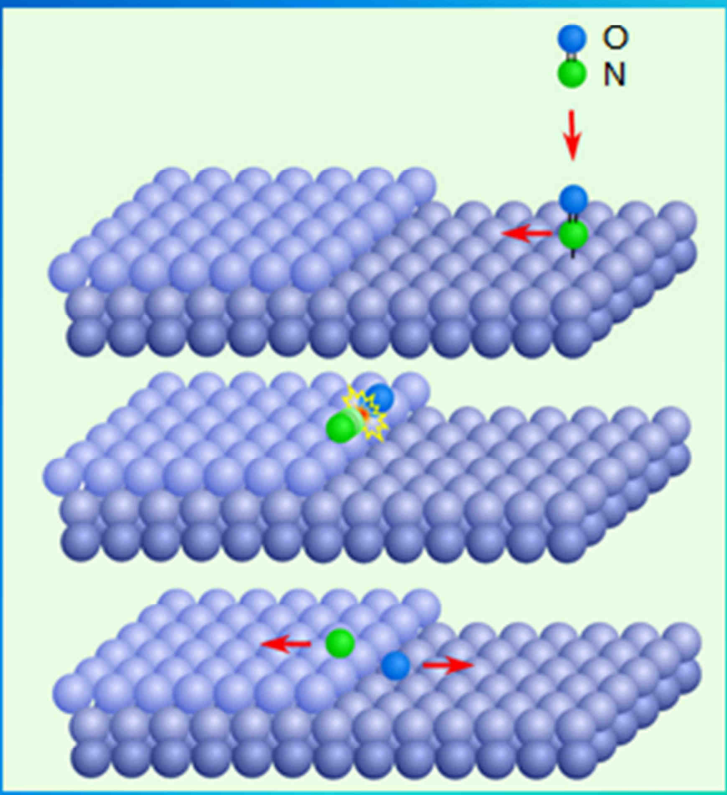

In details: if a NO molecule strikes such a surface, it moves very rapidly and there is a step, where they can dissociate and then their atoms move away from the terrace again.

The role of these steps may be that they are active sites of a catalyst itself, so if there are any impurities, on the other hand, these active sites may be blocked first and that is why very often very small amounts of poison, like sulfur, kill the activity of a catalyst. 


\section{$\mathrm{S} / \mathrm{Al}(\mathbf{1 1 1})$}

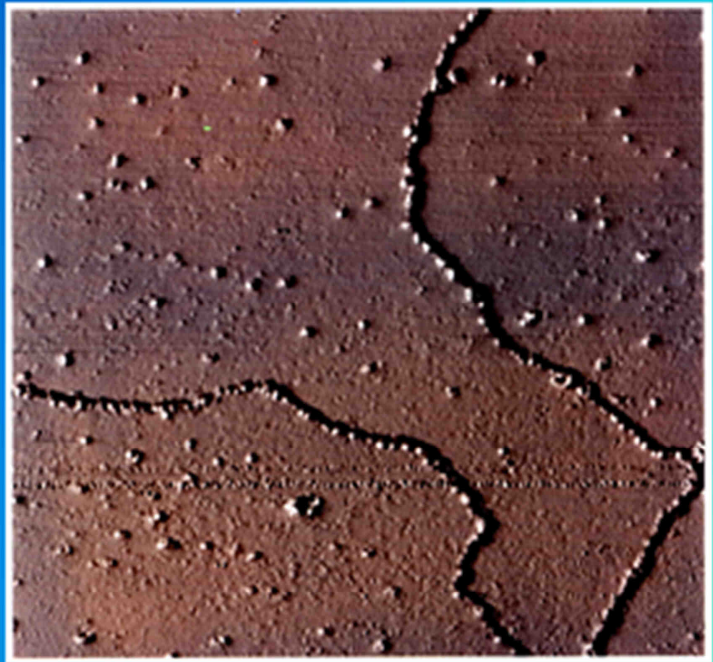

$\longmapsto$

\section{O/Ru(0001)}

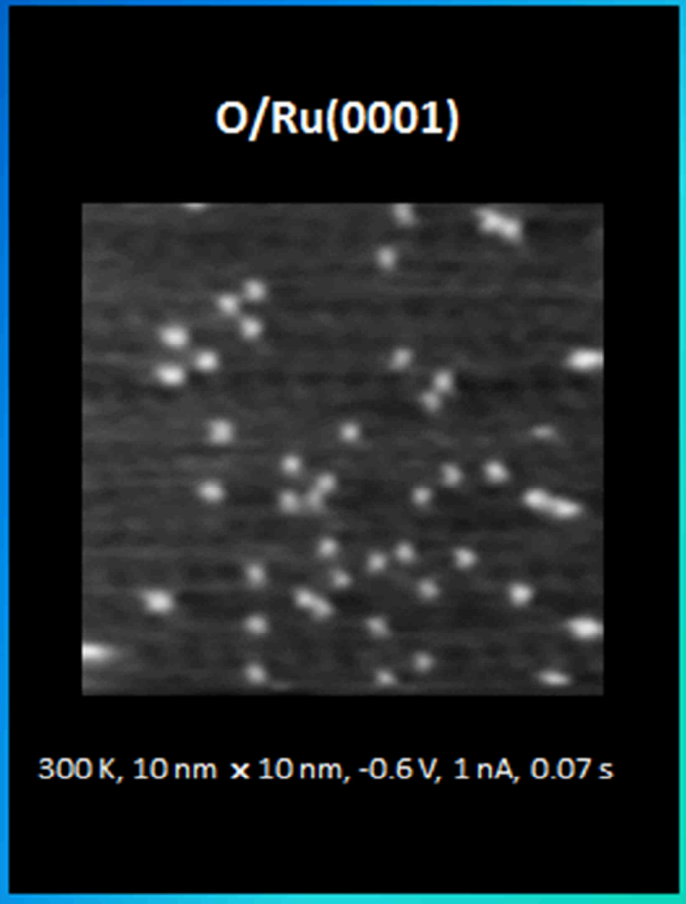

$300 \mathrm{~K}, 10 \mathrm{~nm} \times 10 \mathrm{~nm},-0.6 \mathrm{~V}, 1 \mathrm{nA}, 0.07 \mathrm{~s}$
Here is such a surface with small amount of sulfur.

They are located along the steps and they are killing the activity.

This is a ruthenium surface with oxygen atoms randomly distributed as a result of the dissociative adsorption. This is a snapshot which was taken in 17 milliseconds, because these atoms are mobile at room temperature, so they are constantly moving. 


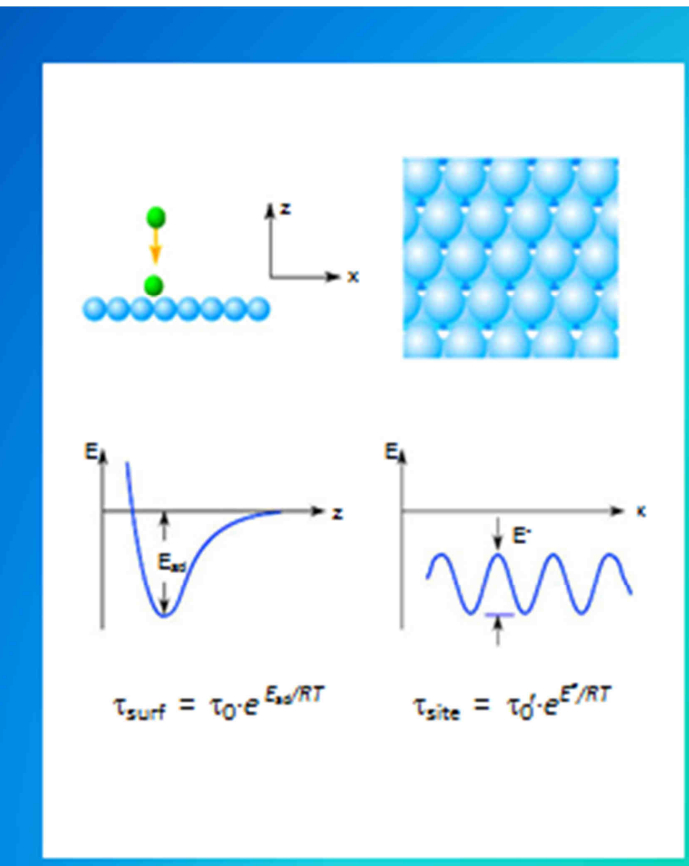

The mobility is illustrated by this figure. If you look at the energetics: if an atom approaches the surface, the potential shows its minimum, which is a strength adsorption, adsorption energy. A lifetime of such atom on the surface is determined by the depths of this potential. If we now move the atom across the surface from one side to another, we have to overcome only the barrier for surface diffusion, which is much smaller, so the molecule or atom can hop from one side to another, depending on activation energy for diffusion and on the temperature. With the oxygen atoms on ruthenium surfaces at room temperature, we have no doubt that they directly follow the motion of atoms on the surface at room temperature in real time.

These are oxygen atoms hopping around on such a surface at room temperature on average safer residence time for about 60 milliseconds at one side. They never seem to come close to each other, but they stay together a little bit longer, because of these attractive interactions mentioned before. And these are the consequences. If we include the low concentrations, they are randomly distributed as they move around like in Brownian motion. But if we increase the concentration, as a consequence of this interactive attractives, we have a new situation, mainly the formation of two phases: a densely packed two-dimensional phase of oxygen atoms and a dilute gas phase, like a solid-gas equilibrium, which we have on the surface. The atoms are continuously attached to the boundary and released back into the gas phase and this condensed phase is a crystalline phase.

We have a well-ordered configuration of the oxygen atoms. And the formation of all that phases on surfaces is more the rule than the exception, because we always have interactions. This can be used to determine the actual structure of these particles adsorbed at the surface by diffraction technique - low energy electric diffraction is suitable enough to determine the structure of these two-dimensional phases. 
$\operatorname{Rh}(111)-(\sqrt{3} \times \sqrt{3}) \mathrm{R} 30^{\circ}-\mathrm{CO} \quad \mathrm{FH}(111)-(2 \times 2)-\mathrm{O} \quad(111)-(2 \times 2)-(\mathrm{O}+1 \mathrm{CO})$

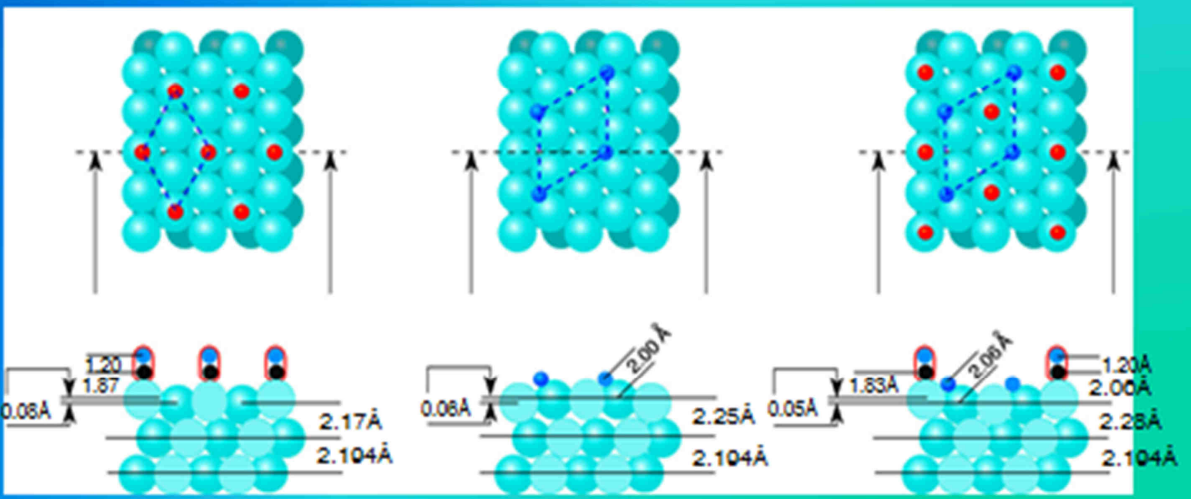

[3] Schwegmann S, Over H, De Renzi V, Ertl G. Surf Sci. 1997;375:91-106.

This is an example of carbon monoxide and oxygen on a rhodium-111 surface. The $\mathrm{CO}$ molecules prefer in this case the top sites (this is a side view). These distances are very similar to distance in carbonyl compounds. The oxygen atoms prefer this three-fold coordinated sides, the hollow sides and form a relatively open mesh (this is a unit cell of the oxygen atoms). As soon as the carbon monoxide concentration exceeds a certain critical value, there is no longer a possibility for oxygen adsorption - the carbon monoxide blocks the sides. Like in your body - if you have $\mathrm{CO}$ there, you can not take up oxygen anymore, you will die. The same happens with car exhaust catalyst - if it is blocked by carbon monoxide, oxygen cannot be adsorbed. On the other hand, if the oxygen atoms form this wired mesh, the carbon monoxide molecules can be adsorbed in between, this is a mixed phase. 


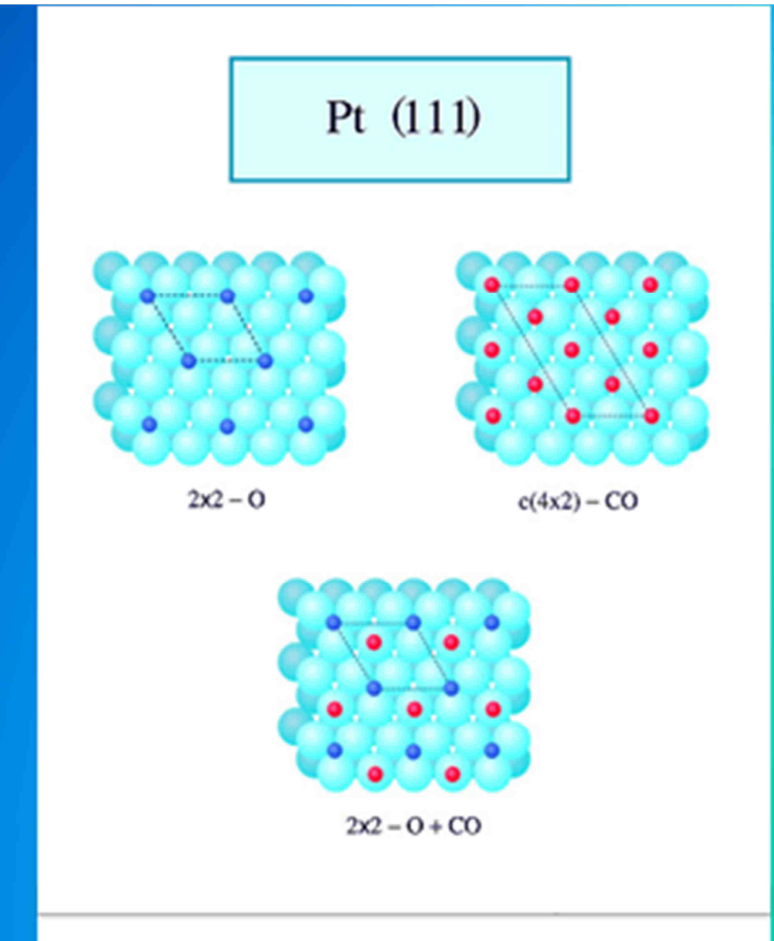

Platinum is very similar. Again, we have this open mesh of oxygen atoms into hollow sides, $\mathrm{CO}$ molecules either on bridge or on top sides in a mixed phase.

[4] Szabo A, Kiskinova M, Yates JT. J Chem Phys. 1989;90:4604.

\section{Catalytic oxidation of $\mathrm{CO}$}
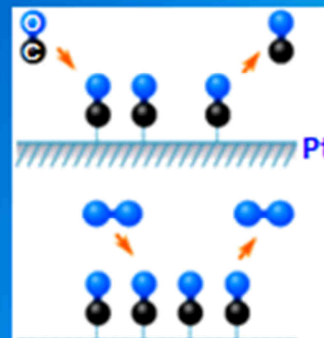
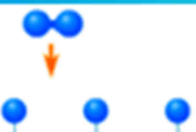

TIIIIIIIIIIImIm!
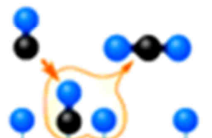

\section{Trmmmmmmmm}

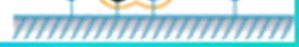

$$
2 \mathrm{CO}+\mathrm{O}_{2} \rightarrow 2 \mathrm{CO}_{2}
$$

$$
\mathrm{CO}+* \rightleftarrows \mathrm{CO}_{\mathrm{ad}}
$$

$$
\mathrm{O}_{2}+2 * \rightleftarrows \mathrm{O}_{2, \mathrm{ad}} \rightarrow 2 \mathrm{O}_{\mathrm{ad}}
$$

$$
\mathrm{O}_{\mathrm{ad}}+\mathrm{CO}_{\mathrm{ad}} \rightarrow \mathrm{CO}_{2}+2 *
$$

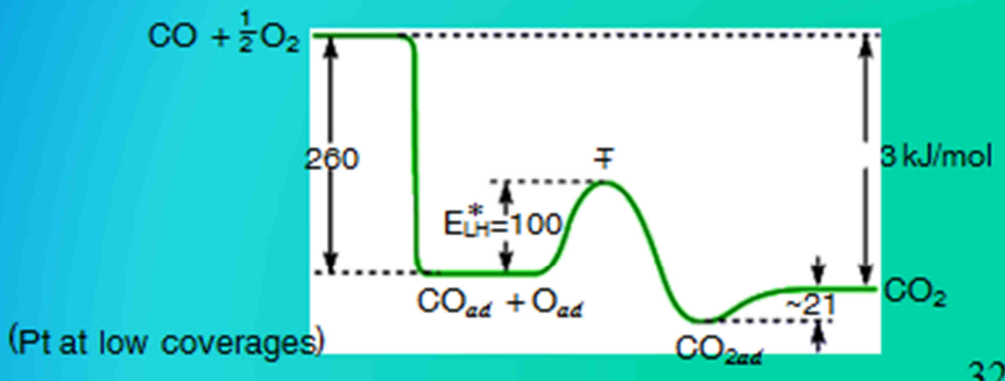


If you have a contimuous flow of oxygen and carbon monoxide, the mechanism is the following. The $\mathrm{CO}$ molecules have the tendency to form this densely packed layer, the oxygen forms its own measures. If posed particles are present on the surface, the surface will be covered by carbon monoxide, because oxygen can no longer be adsorbed. Only if the $\mathrm{CO}$ concentration is below a certain limit, oxygen can be absorbed and they can form the $\mathrm{CO}_{2}$. This can only be achieved if the temperature's high enough. This is why the car exhaust catalyst is not working at a room temperature - you have to go up to about 150 or 200 degree centigrade, so the part of the $\mathrm{CO}$ is always desorbing and then in the flow conditions you have posed particles, $\mathrm{CO}$ and oxygen on the surface, which may interact and form $\mathrm{CO}_{2}$. This is a sequence of steps: $\mathrm{CO}$ is adsorbed, oxygen dissociating through a molecular state, absorbed and it will recombine to $\mathrm{CO}_{2}$. And this is an energy profile shown through action of a catalyst in the beginning: you start with carbon monoxide and oxygen, we end with $\mathrm{CO}_{2}$. This is the reaction enthalpy, but most of this reaction enthalpy is released, it's a first step - by the adsorption of $\mathrm{CO}$ and oxygen. And if they are both in close vicinity, they are semi-directly overcoming an activation barrier of about $100 \mathrm{~kJ}$, which is easily accessible at room temperature. $\mathrm{CO}_{2}$ is formed and then released back into the gas phase. The same goes for platimum, rhodium, palladium, but not for ruthenium. Ruthenium is also a platinum model but as a metal it is a very, very bad catalyst. Only if you operate ruthenium catalyst for a longer period, it becomes active.

$$
2 \mathrm{CO}+\mathrm{O}_{2} \rightarrow 2 \mathrm{CO}_{2} / \mathrm{Ru}(0001)
$$

$$
\mathrm{Pco}=10 \mathrm{mbar}, \mathrm{Po}_{2}=50 \mathrm{mbar}, \mathrm{T}=450 \mathrm{~K}
$$

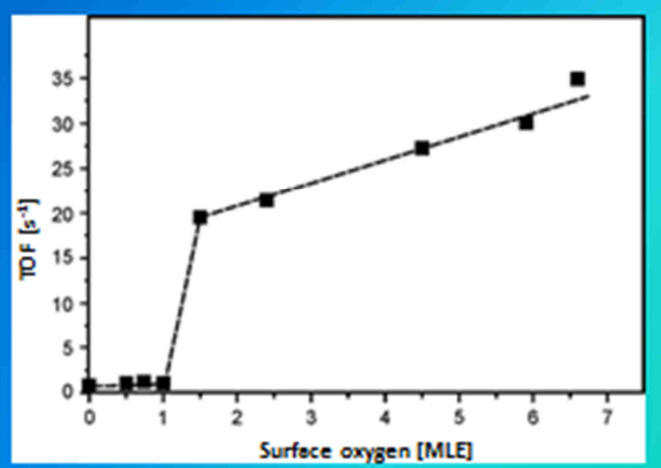

Catal Lett. 2012;142:657-663.
This is shown here - the rate of $\mathrm{CO}_{2}$ formation with a ruthenium surface. The rate is expressed in terms of turnover frequency - the number of $\mathrm{CO}$ molecules transformed into $\mathrm{CO}_{2}$ per second. And as long as the concentration on the surface of oxygen is low, there is no activity. Only if there are more of the monolayers of oxygen on the surface the activity goes up. It becomes larger, if the oxygen concentration becomes larger, as well. The oxygen obviously oxidizes the surface, so the catalyst itself is chemically transformed and this is a very often case - the catalyst is changing its chemical structure under the reaction conditions.

[5] Martynova Y, Yang B, Yu A, Boscoboinik JA, Shaikhutdinov S, Freund HJ. 


\section{$\mathrm{RuO}_{2}(110)+1 \times 1-\mathrm{O} / \mathrm{Ru}(0001)$}
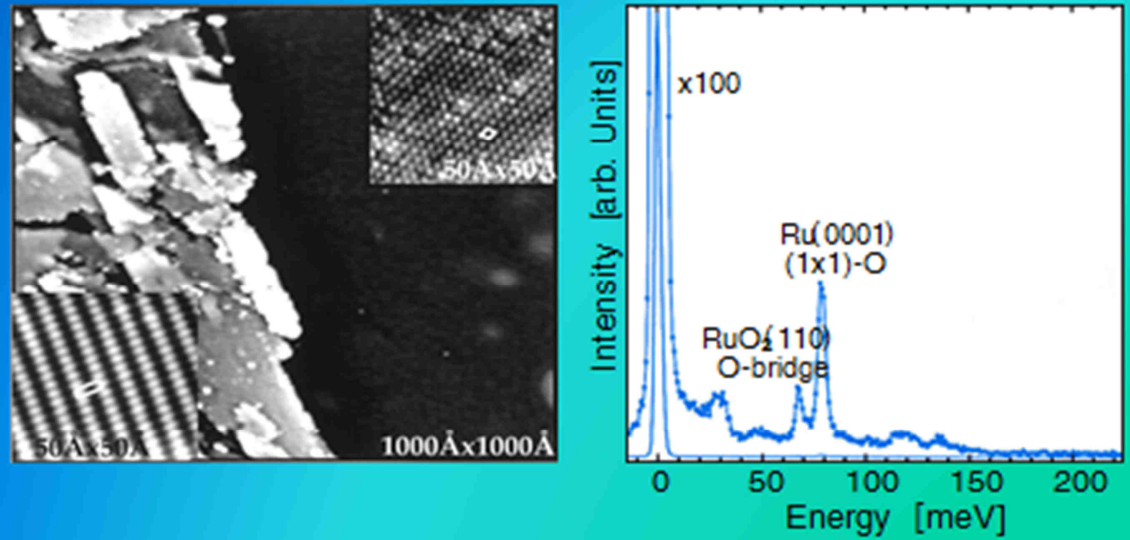

In this case we are transforming the surface of ruthenium, which arranges the oxygen atoms into a new phase - it is a ruthenium dioxide-110 surface, which is catalytically very active.

[0] Over H, Kim YD, Seitsonen AP, Wendk S, Lundgren E, Schmidt M, et al. Science.
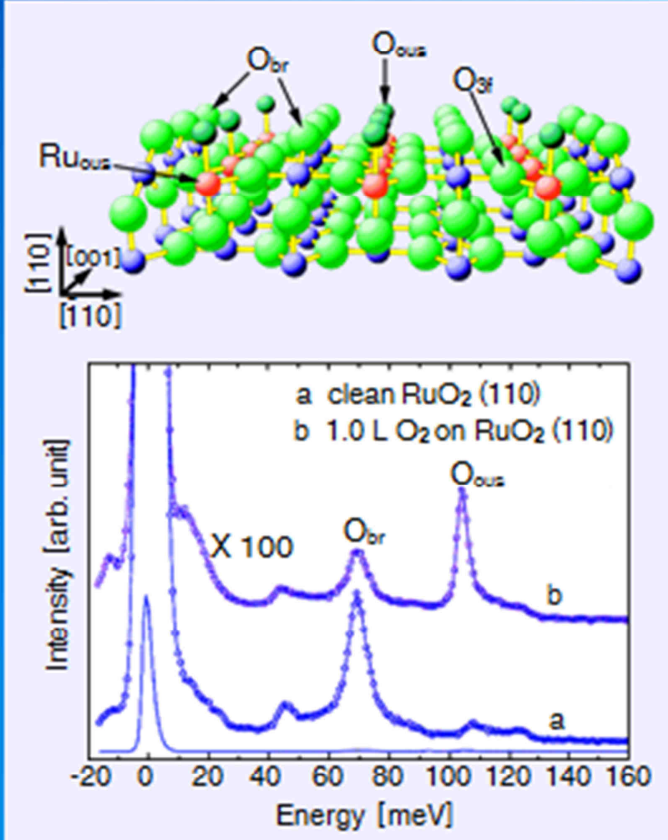

It exposes ruthenium atoms, which can be occupied by oxygen or biomolecules.

[7] Fan CY, Wang J, Jacobi K, Ert1 G. J Chem Phys. 2001;114:10058-10062. 


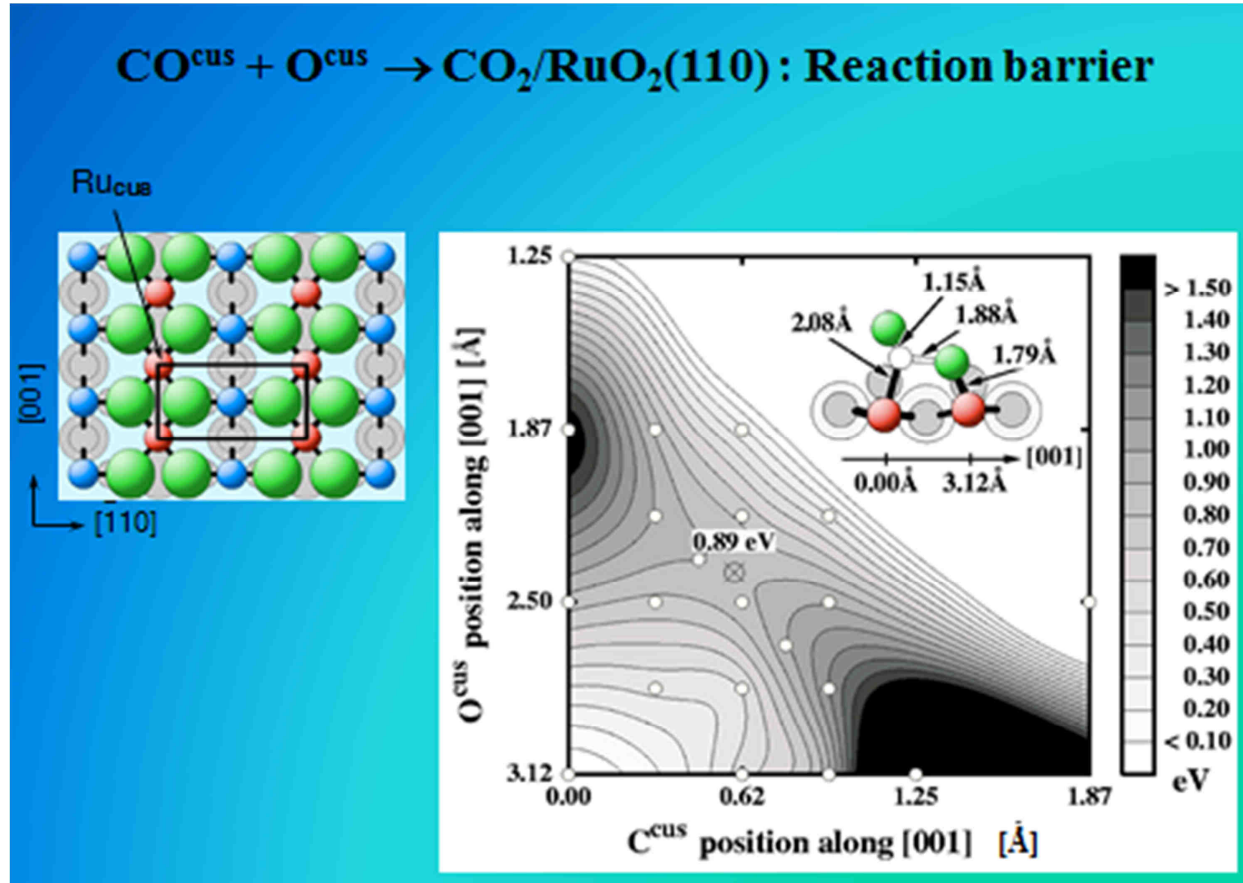

[8] Reuter K, Scheffler M. Phys Rev B. 2003;68:045407-045411.

In theory we are now able to calculate energetics and the rate of such processes. And this could be done, in this case, for $\mathrm{CO}$ molecules and oxygen atoms in close vicinity along these rows of unsaturated sites on the surface. This is an energy profile - the $\mathrm{CO}$ molecule and the oxygen atoms approach each other along this direction, as there is a barrier of about $0.9 \mathrm{eV}$, which is an activation energy to recombine oxygen and $\mathrm{CO}$ molecules and form $\mathrm{CO}_{2}$. This is a quantum theory, without any parameters. Now we can really measure the rate of $\mathrm{CO}_{2}$ formation under steady state conditions and compare the rate calculated on this basis. 


\section{$2 \mathrm{CO}+\mathrm{O}_{2} \rightarrow 2 \mathrm{CO}_{2} / \mathrm{RuO}_{2}(110)$}

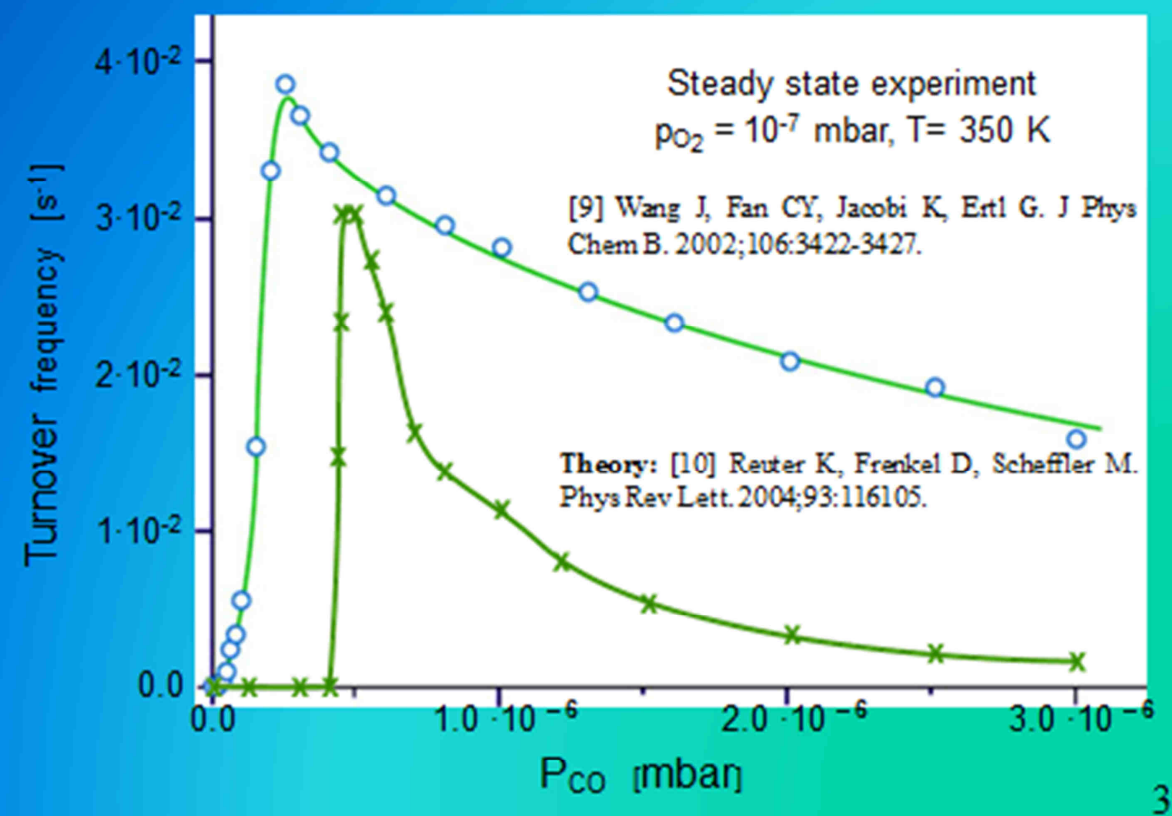

This is shown here. The rate depends partially on the pressure of $\mathrm{CO}$ and partially on the pressure of oxygen and temperature. If we keep the oxygen pressure and the temperature constant, then the rate will be a function of the $\mathrm{CO}$ pressure against the turnover frequency. If you start with a small $\mathrm{CO}$ concentration, then the rate will continuously increase and then we reach the maximum, where the steady state concentration of oxygen and $\mathrm{CO}$ on the surface are about equal. If we increase the pressure, the rate will go down again. This is typical for such type of a surface reaction. These are the absolute numbers of turnover frequencies both from $x$-ray and there are no adjustable parameters at all. The agreement is not perfect, but it is very good, there is very, very small difference between the maximum rates and this shows that in principle quantum theory is now able to calculate, to predict the behavior of a catalytic surface in several cases. 


\section{Selectivity}

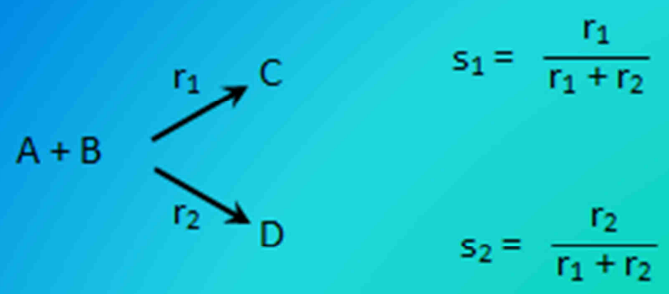

Very often not only a single product is formed, but different products are also formed and the role of the catalyst is not so much linked exactly with the activity but the selectivity. If from $A$ and $B$ two different reaction products, $C$ and $D$, can be formed, selectivity is the ratio of the rate from formation of $C$ or the formation of the product $\mathrm{D}$ over the total rate.

\section{Selective oxidation of ammonia on $\mathrm{RuO}_{2}(110)$}

\section{Mechanism}

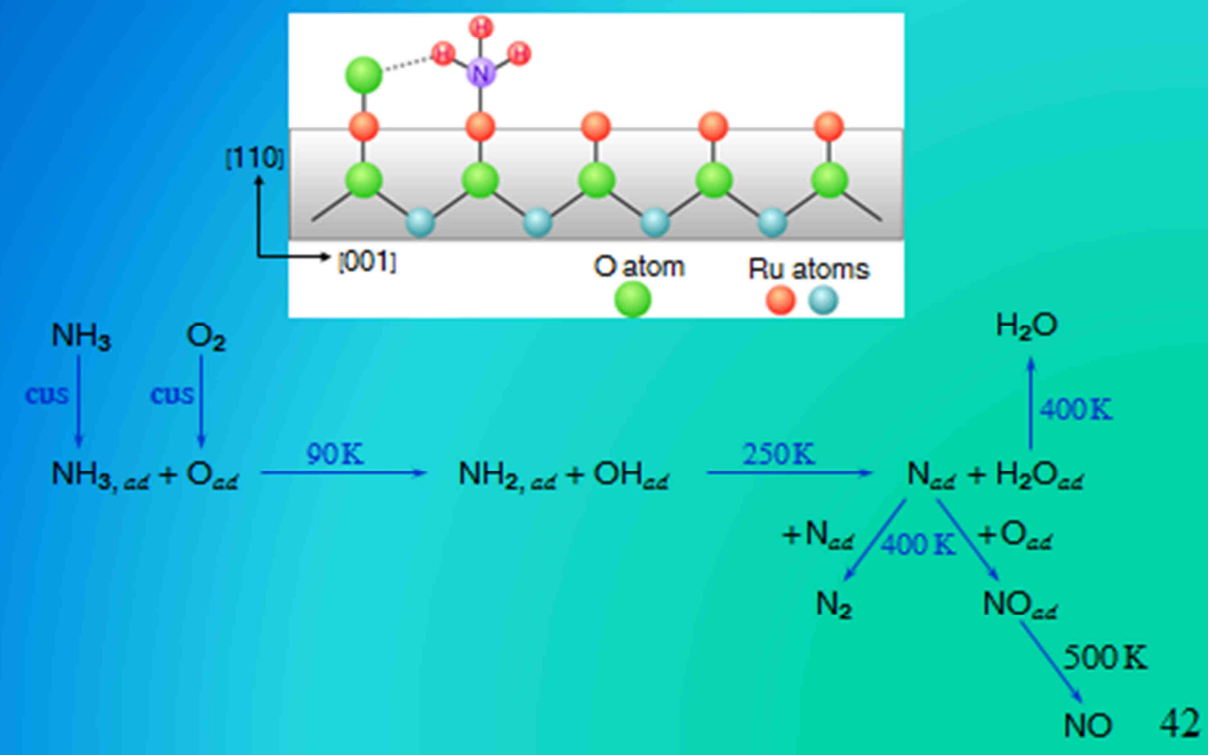


An example is shown here. The oxidation of ammonia on ruthenium dioxide. This is a process, which is also applied in the industry for the formation of the nitric acid. Again, the rate will be dependent on pressure of ammonia, pressure of oxygen and the temperature. If we keep the ammonia and oxygen pressures and the temperature constant, the rate of formation of nitrogen rises, goes to the maximum then decreases again as the rate of the NO formation rises continuously. The selectivity for $\mathrm{NO}$ formation increases continuously up to about $80 \%$. The selectivity depends on the ratio of reacting molecules.

\section{Selective oxidation of ammonia on $\mathrm{RuO}_{2}(110)$}

Steady-state kinetics and modelling $T=500 \mathrm{~K} \quad \rho\left(\mathrm{NH}_{3}\right)=1 \cdot 10^{-7} \mathrm{mbar}$
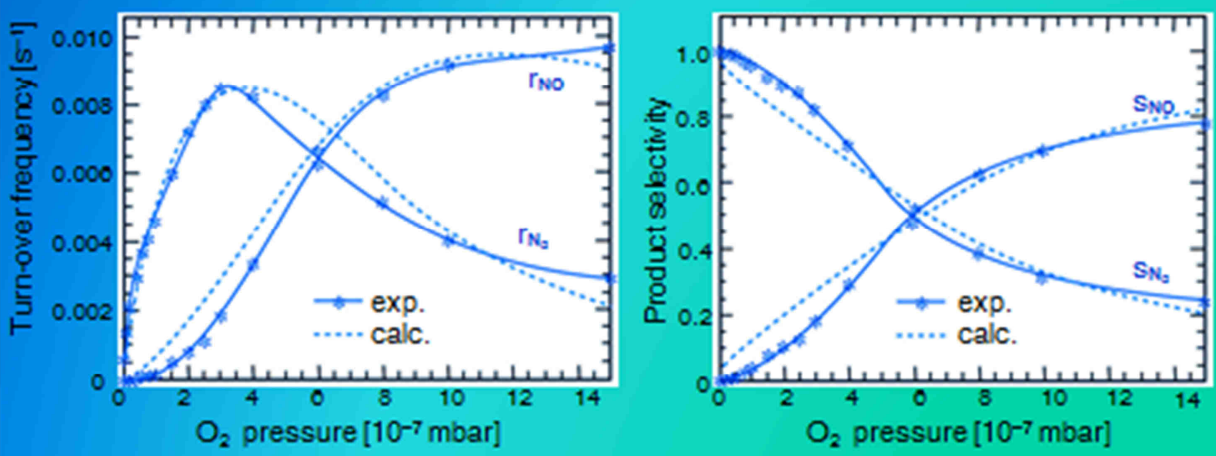

[11] Wang Y, Jacobi K, Schoene WD, Ert G. J Phys Chem B. 2005;109:7883-7893.

[12] Hong S, Karim A, Rahman TS, Jacobi K, Ertl G. J Catal. 2010;276:371-381. 
This is a consequence of the mechanism of this reaction. We have the surface exposing the ruthenium atoms onto which is oxygen atoms or ammonia molecules are absorbed and if they are neighboring there is an interaction between the oxygen and the ammonia (through a hydrogen bridge). This is a very rapid process, it takes place at a very low temperature. One of the hydrogen atoms is abstracted and in higher temperature other hydrogen atoms are abstracted along with nitrogen atoms, water is formed and then we have no oxygen atoms on the surface and the nitrogen atoms and it depends on the ratio of the two whether the nitrogen atoms recombine into $\mathrm{N}_{2}$ or recombine with oxygen into NO. So it is the ratio of oxygen and the ammonia that determines the selectivity of the overall process. Again, this can be modeled by theory.

Growth increase of tree following administration of ammonia fertilizer

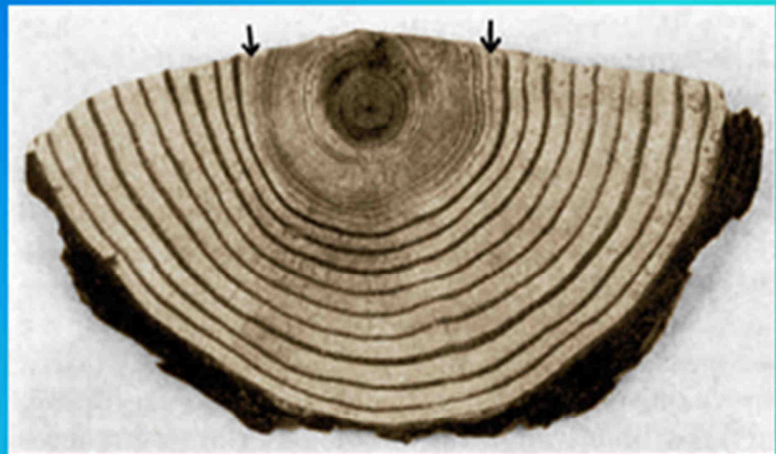

This is a cut through a tree from a wood in Norway. You see the rings of the growth in the years. At the beginning these rings were very close that means the growth was very slow. After 25 years these woods were administered with nitrogen fertilizer - they were fertilized or sprayed. And you see how the growth increased (there are larger distances). So the fertilizer has a very strong influence on the growth of these woods. Until about 1900 there were not enough natural sources for nitrogen fertilizers, but then the growth of the Earth population caused really serious problems and there was a bad need for the formation of nitrogen fertilizers. This could be achieved by Haber in the laboratory and Bosch with Haber were the first to do it, so that is why it is called a 'Haber-Bosch process'. 


\section{Catalytic synthesis of ammonia}

(Haber-Bosch process)



$\underline{\mathrm{N}}_{2}+3 \mathrm{H}_{2} \rightarrow 2 \mathrm{NH}_{3}$

$\mathrm{T} \approx 400^{\circ} \mathrm{C}, \mathrm{p} \approx 300 \mathrm{~atm}$.

promoted iron catalyst

It is a large-scale industrial process nowadays - the formation of ammonia from nitrogen from the air and hydrogen. It is taking place in large-scale chemical plants at higher temperature and higher pressures using very complicated catalyst, the so-called 'promoted iron catalyst'.

\section{World population and ammonia production}

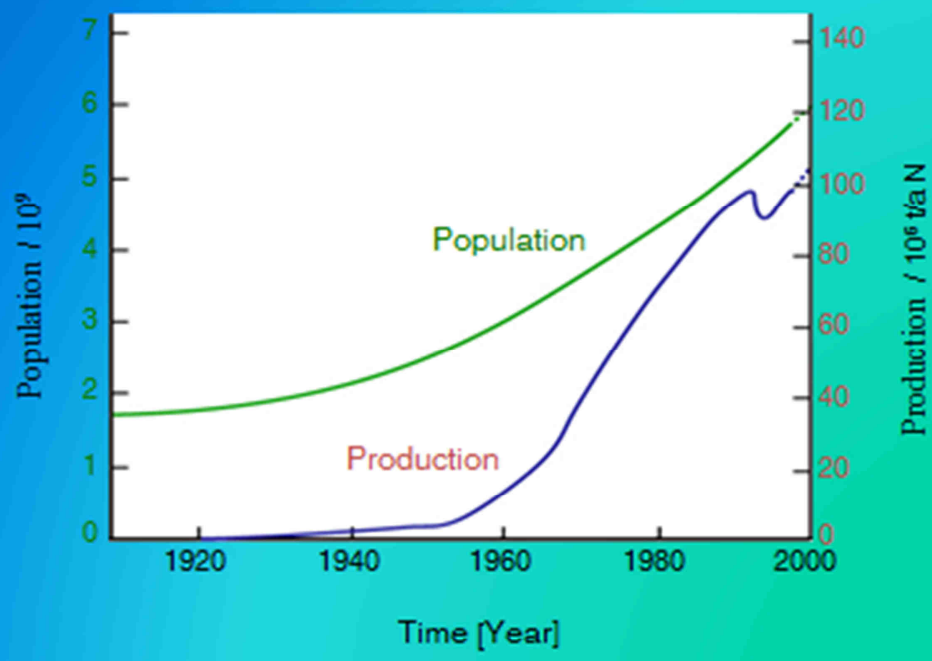


The role of this production can be shown here, in this diagram. It shows the growth of the world population and the production of ammonia over the years. It is very clear that without the formation of ammonia, our population would starve - about $30 \%$ of the world's population would die, because there would be not enough food available. A huge progress was made by the formation of ammonia which is the basis for nitrogen fertilizers. Nowadays about 100 million tons of ammonia are used in fertilizers per year and about $2 \%$ of the total energy consumption arises from this industry. If it would be possible to find a process, which is working with lower energy costs, this would have enormous consequences, but so far it is still not possible.

\section{Catalytic synthesis of ammonia}

\section{(Haber-Bosch process)}

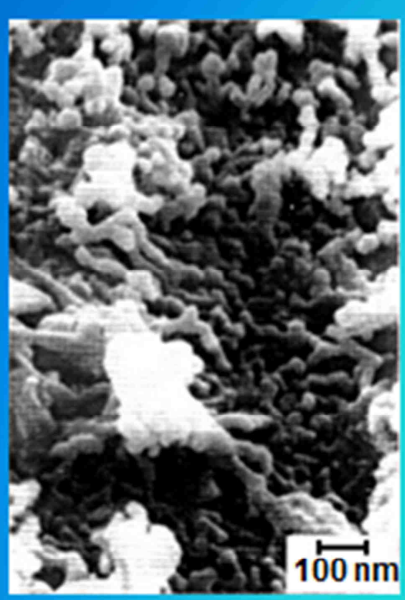

$$
\mathrm{N}_{2}+3 \mathrm{H}_{2} \Leftrightarrow 2 \mathrm{NH}_{3}
$$

Technical conditions: $T \approx 400^{\circ} \mathrm{C}, \mathrm{p} \approx 300$ bar promoted iron catalyst

$$
\text { BASF S6-10 catalyst (at. \%) }
$$

\begin{tabular}{lrlrll} 
& $\mathrm{Fe}$ & \multicolumn{1}{l}{$\mathrm{K}$} & $\mathrm{Al}$ & $\mathrm{Ca}$ & $\mathrm{O}$ \\
Bulk composition & 40.5 & 0.35 & 2.0 & 1.7 & 53.2 \\
Surface- & & & & & \\
$\quad$ unreduced & 8.6 & 36.2 & 10.7 & 4.7 & 40.0 \\
reduced & 11.0 & 27.0 & 17.0 & 4.0 & 41.0 \\
cat. active spot & 30.1 & 29.0 & 6.7 & 1.0 & 33.2
\end{tabular}


The process is based on a catalyst which was invented in 1910 and still the same one is being used in plants all over the world. This is the catalyst, it looks very complicated. It is a promoted iron catalyst. This is a scaming electron micrograph showing this catalyst particles, which is of different composition, obviously. The composition is essentially Fe(III) or (IV) oxide with small amounts of potassium, aluminum and calcium. These elements are very important, they are the so-called 'promoters'. Without these promoters the catalyst would not be active enough. What is the role of these small amounts of promoters? They are embedded between the catalytically active sites of particles of iron. The oxides of calcium form a framework which prevent the catalyst from sintering at higher temperatures. This is a so-called 'structural promoter'. As for potassium, the surface concentration of potassium is quite different. The active spots of iron are uniformly covered by potassium plus oxygen. This very small concentration of potassium spreads over the surface and forms the so-called 'electronic promoter', which enhances the activity for the formation of dissociative adsorbed nitrogen atoms. This is a decisive step.
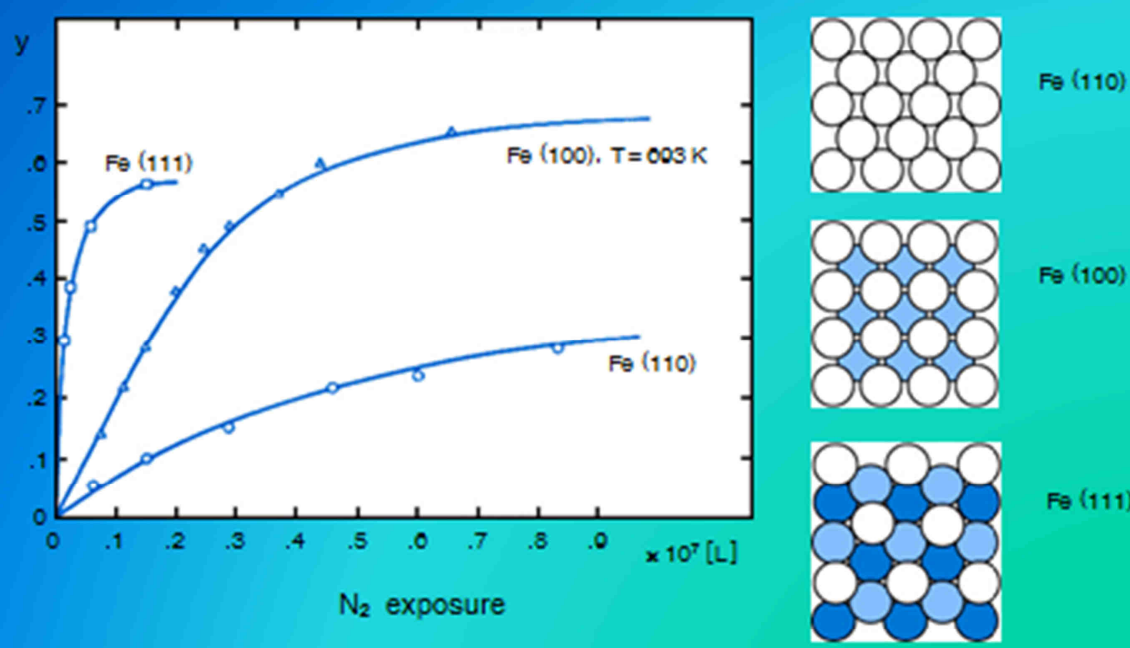

This dissociation of nitrogen atoms on the surface depends on the structure. This is, again, a crystal surface, the most densely baked. This shows the uptake of nitrogen atoms as a function of the exposure to nitrogen molecules. The activity is the highest when there are more open plains that are active sites. This activity can be enhanced by the presence of potassium because potassium donates electrons to the substrate and these electrons can be used to increase the rate of uptake of nitrogen. 


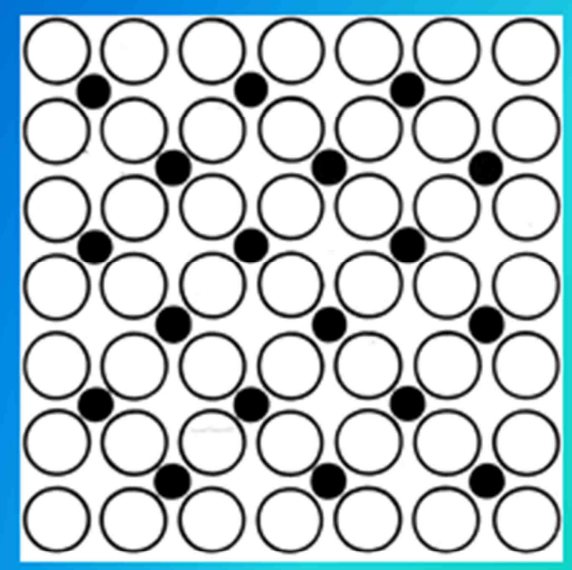

\section{$\mathrm{N} / \mathrm{Fe}(100)$}

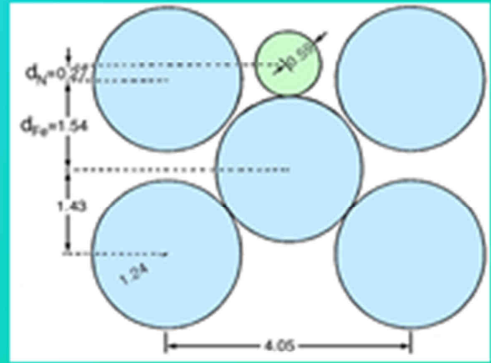

This is a structure of all of these phases. Nitrogen atoms are embedded in the topmost layer of iron atoms.

\section{Mechanism of catalytic ammonia synthesis}

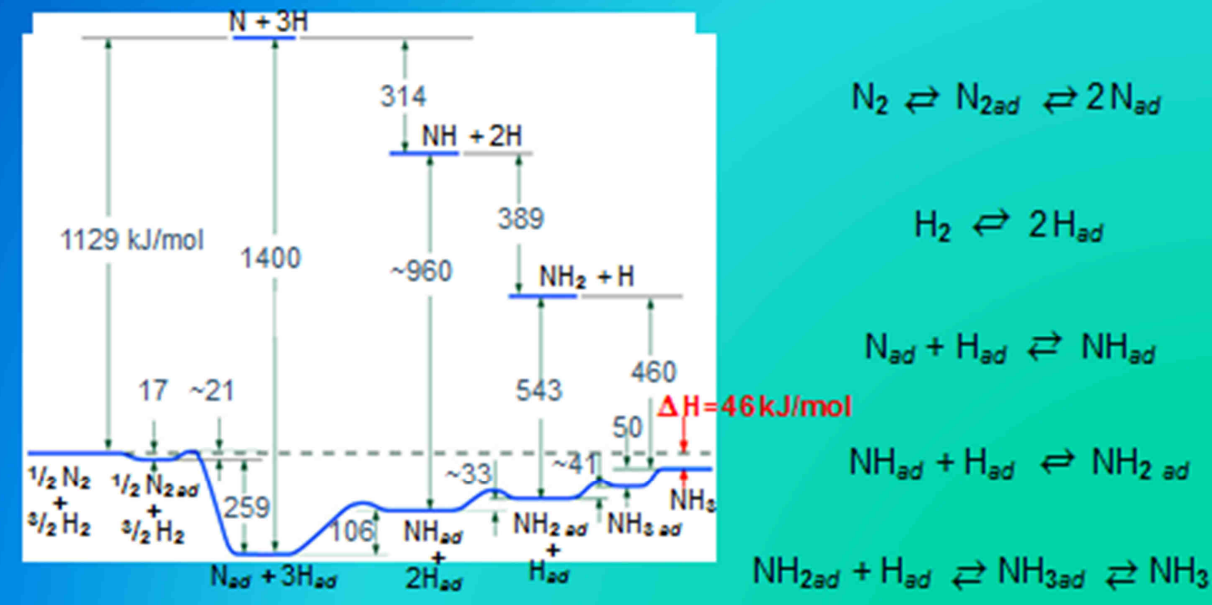


This is a summary of the mechanisms of this catalytic reaction of ammonia. We start with nitrogen and hydrogen and end up with ammonia. If you would like to perform this reaction into the gas phase by first dissociating nitrogen and hydrogen you would need an immense amount of energy. If you would have these atoms, they could recombine stepwise and always gain energy, but this is prohibitive, this does not take place. Instead, the catalyst offers you an alternative route. Some nitrogen molecules are first adsorbed and then they can overcome the barrier for dissociation, like the oxygen molecules we have seen before. They can form the nitrogen atoms on the surface and the hydrogen atoms are also adsorbed and now they can recombine stepwise and direction is going uphill. All these different steps could be identified. This way the overall reaction path can be modeled

\section{Conclusions}

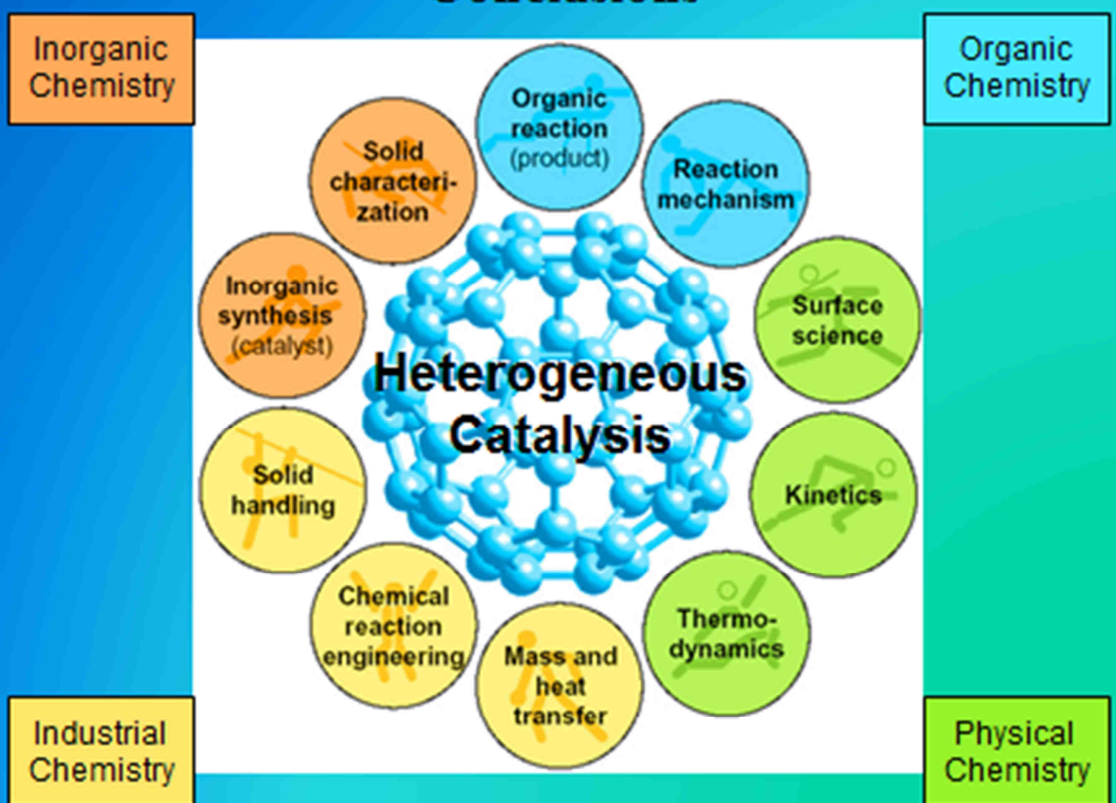


The heterogeneous catalysis is very important for all these aspects of environmental chemistry. The heterogeneous catalysis is a discipline, which involves all the different aspects of chemistry, iinorganic and analytical chemistry in order to characterize the catalysts and the forms of catalysts.

We talked mainly about the application of surface science, physical chemistry to identify elementary steps to form kinetic loss and determine the damage of this reaction. And then the industrial chemistry has to put all these things together to understand the solid handling, chemical reaction and energy engineering and the heat and mass transfer in these catalytic processes.

This is a wide field and there are many open questions. We did not address all the problems concerning energy conservation and energy transformation, so there is still much to do in the future.

\section{Literature}

[1] Winterlin J, Schuster R, Ert1 G. Existence of a "Hot" Atom Mechanism for the Dissociation of $\mathrm{O}_{2}$ on Pt(111). Phys Rev Lett. 1996;77:123-129. DOI: 10.1103/PhysRevLett.77.123.

[2] Zambelli T, Wintterlin J, Trost J, Ertl G. Identification of the 'active sites' of a surface-catalyzed reaction. Science. 1996;273:1688-1690. DOI: 10.1126 science.273.5282.1688.

[3] Schwegmann S, Over H, De Renzi V, Ertl G. The atomic geometry of the $\mathrm{O}$ and $\mathrm{CO}+\mathrm{O}$ phases on Rh(111). Surf Sci. 1997;375:91-106. DOI: 10.1016/S0039-6028(97)01249-1.

[4] Szabo A, Kiskinova M, Yates JT. J Chem Phys. 1989;90:4604. DOI: 10.1063/1.456620.

[5] Martynova Y, Yang B, Yu A, Boscoboinik JA, Shaikhutdinov S, Freund HJ. Low Temperature CO Oxidation on Ruthenium Oxide Thin Films at Near-atmospheric Pressures. Catal Lett. 2012;142:657-663. https://ink.springer.com/article/10.1007/ s10562-012-0823-3.

[6] Over H, Kim YD, Seitsonen AP, Wendt S, Lundgren E, Schmidt M, et al. Atomic-scale structure and catalytic reactivity of the $\mathrm{RuO}_{2}(110)$ surface. Science. 2000;287:1474-1476. DOI: $10.1126 /$ science.287.5457.1474. 


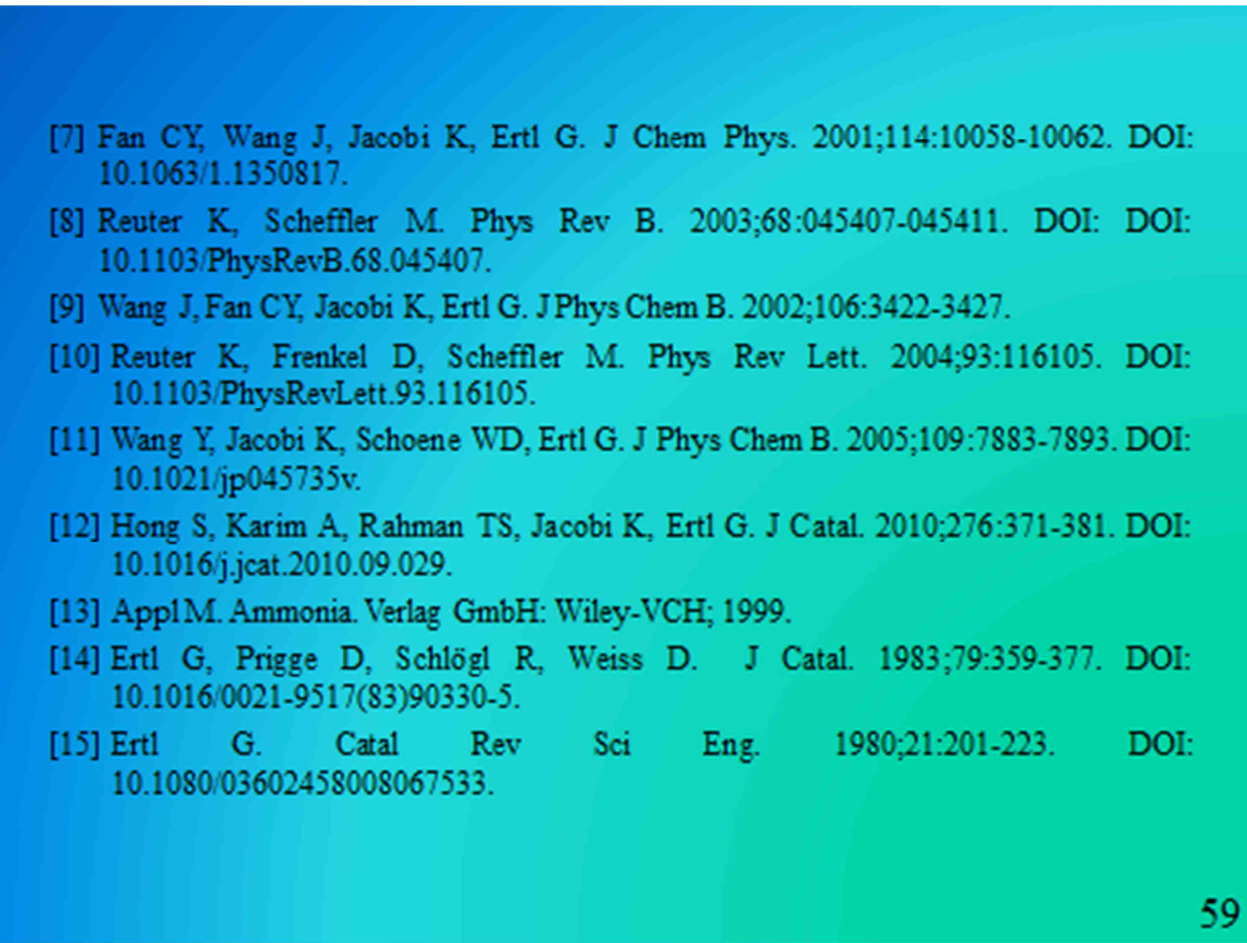

\title{
PODSTAWOWE KROKI W KATALIZIE HETEROGENNEJ: PODSTAWY DLA CHEMII ŚRODOWISKA
}

\author{
${ }^{1}$ Fritz-Haber-Institut der Max-Planck-Gesellschaft, Berlin, Niemcy \\ ${ }^{2}$ Samodzielna Katedra Biotechnologii i Biologii Molekularnej, Uniwersytet Opolski, Polska
}

\begin{abstract}
Abstrakt: Kataliza stała się obecnie alternatywnym sposobem na natychmiastowe tworzenie produktu chemicznego $\mathrm{z}$ uwagi na niższą barierę energetyczną (między cząsteczkami a katalizatorami). Kataliza heterogenna obejmuje przyspieszenie reakcji chemicznej poprzez oddziaływanie cząsteczek związanych z powierzchnią ciała stałego. Jest to dyscyplina, która obejmuje różne aspekty chemii: chemię nieorganiczną i analityczną w celu scharakteryzowania katalizatorów i form tych katalizatorów. Chemia przemysłowa następnie łączy te wszystkie zagadnienia razem, aby zrozumieć chemiczną manipulację ciał stałych, reakcję chemiczną i inżynierię energetyczną oraz przenoszenie ciepła i masy w tych procesach katalitycznych. Bardzo często tworzy się nie jeden, lecz kilka produktów, wtedy rola katalizatora nie jest tak bardzo związana $\mathrm{z}$ aktywnością, ale z selektywnością. Podstawowe etapy można teraz zbadać w skali atomowej, co będzie zilustrowane głównie dwoma przykładami: utlenianiem tlenku węgla (katalizator spalin samochodowych) i syntezą amoniaku (podstawa nawozu azotowego). Istnieje ogromny rynek katalizatorów pomimo wysokich ich kosztów. Duża ich część jest stosowana w samochodach, w rafineriach ropy naftowej i przemysłowych procesach czyszczenia. Procesy katalityczne stanowią szeroki obszar badań i nadal istnieją liczne problemy związane z oszczędzaniem i transformacją energii.
\end{abstract}

Słowa kluczowe: kataliza heterogenna, chemia środowiska, utlenianie tlenku węgla, synteza amoniaku 